\title{
Frugal Chemoprevention: Targeting Nrf2 with Foods Rich in Sulforaphane
}

\author{
Li Yang ${ }^{1}$, Dushani L. Palliyaguru' ${ }^{2}$, Thomas W. Kensler ${ }^{1,2}$ \\ ${ }^{1}$ Li Yang, PhD, Research Associate, Department of Pharmacology \& Chemical \\ Biology, University of Pittsburgh School of Medicine, Pittsburgh, PA 15261 \\ ${ }^{2}$ Dushani L. Palliyaguru, PhD candidate, Department of Environmental and \\ Occupational Health, University of Pittsburgh Graduate School of Public Health,
}

Pittsburgh, PA 15261

\section{Acknowledgements}

We thank the National Institutes of Health (P01 ES006052, R01 CA94076) the

Breast Cancer Research Foundation and the Department of Defense W81XWH-

08-1-0176 for support.

\section{The corresponding author:}

Thomas W Kensler, PhD, BSTWR E1352, Department of Pharmacology \&

Chemical Biology, University of Pittsburgh, Pittsburgh PA 15261.

Department of Environmental and Occupational Health, University of Pittsburgh

Graduate School of Public Health, Pittsburgh, PA 15261

E-mail: tkensler@pitt.edu Phone: 412-648-1942 Fax: 412-648-1945 


\begin{abstract}
With the properties of efficacy, safety, tolerability, practicability and low cost, foods containing bioactive phytochemicals are gaining significant attention as elements of chemoprevention strategies against cancer. Sulforaphane [1isothiocyanato-4-(methylsulfinyl)butane], a naturally occurring isothiocyanate produced by cruciferous vegetables such as broccoli, is found to be a highly promising chemoprevention agent against not only variety of cancers such as breast, prostate, colon, skin, lung, stomach or bladder carcinogenesis, but also cardiovascular disease, neurodegenerative diseases, and diabetes. For reasons of experimental exigency, pre-clinical studies have focused principally on sulforaphane itself, while clinical studies have relied on broccoli sprout preparations rich in either sulforaphane or its biogenic precursor, glucoraphanin. Substantive subsequent evaluation of sulforaphane pharmacokinetics and pharmacodynamics has been undertaken using either pure compound or food matrices. Sulforaphane affects multiple targets in cells. One key molecular mechanism of action for sulforaphane entails activation of the Nrf2- Keap1 signaling pathway although other actions contribute to the broad spectrum of efficacy in different animal models. This review summarizes the current status of pre-clinical chemoprevention studies with sulforaphane and highlights the
\end{abstract}


progress and challenges for the application of foods rich in sulforaphane and/or glucoraphanin in the arena of clinical chemoprevention.

\section{INTRODUCTION}

Aging and growth of the world population, together with adoption of lifestyle factors such as smoking, obesogenic diets, and sedentary habits are escalating the global burden of cancer. According to World Cancer Report 2014, it is estimated that 8.2 million cancer deaths occurred in 2012 and that this toll will reach more than 14 million by 2030. Over two-thirds of this burden will reside in the developing and recently developed world. A substantial proportion of the worldwide burden of cancer could be prevented through the application of existing knowledge of cancer control and by implementing programs for tobacco control, vaccination, and early detection and treatment, as well as public health campaigns promoting physical activity and consumption of healthier diets ${ }^{1}$. Prevention trials using whole foods or simple extracts offer additional prospects for reducing this expanding burden of cancer effectively, and in contrast to promising isolated phytochemicals or pharmaceuticals, frugally. Combined modification of diet and behavior constitute one of the only available tools for widespread change in many populations in the developing world. Here especially, the practice of frugal medicine becomes essential; interventions need to be effective, safe, tolerable, practical, and inexpensive. While the science of chemoprevention in the US and Europe largely follows in the footsteps of 
precision medicine, seeking ever better defined markers of individual risk for cancer coupled to molecular targeting of agents, the economic realities argue that most of the world population at risk for cancer will not have access to new generation-targeted synthetic molecules for either treatment or prevention. They will have access, however, to local foodstuffs containing bioactive phytochemicals. Thus, an appreciation of the mechanisms of chemopreventive action of such phytochemicals will facilitate the utilization of indigenous protective foods or perhaps guiding the introduction of culturally appropriate new foods into their diets.

Dozens of non-nutrient phytochemicals have been described as inhibitors of experimental carcinogenesis, and have been reviewed extensively ${ }^{2,3,4}$. Many of these compounds come from foods - vegetables, fruits, herbs, spices, and teas. There is ample evidence to suggest that whole foods themselves may be the most effective way to reduce the risk of a variety of cancers and that the delivery of complex mixtures of a number of individually bioactive phytochemicals permits the up-regulation and/or inhibition of multiple steps in the development of neoplasias: polypharmacy in a food in a manner comparable to combinatorial approaches in therapy. Use of food matrices for the delivery of bioactive phytochemicals facilitates the frugality of the approach but clouds the understanding of the underlying pharmacology driving the protective efficacy. Favorite molecular pathways may be used to identify bioactive molecules, to 
enrich the selection of foodstuffs, to enable quality control of test materials, and to provide guideposts for the pharmacodynamic evaluation of interventions. It is in this context that several laboratories are targeting the Nrf2 cell signaling pathway with chemopreventive agents.

\section{MOLECULAR TARGETS OF SULFORAPHANE: NRF2 SIGNALING}

\section{PATHWAY}

Certain inherent molecular pathways are able to protect cells and organisms against carcinogenesis, mutagenesis and other forms of toxicity. Nrf2, a transcription factor that belongs to the Cap 'n' Collar basic leucine zipper transcription factor family, is one such modifier that is also considered to be a master regulator of the environmental stress response. Under quiescent conditions, Nrf2 is held in the cytoplasm by Keap1, which facilitates its degradation via ubiquitination then proteolysis by the $26 \mathrm{~S}$ proteasomal complex ${ }^{5,6}$. Under conditions of electrophilic, oxidative and inflammatory stresses this proteolysis is interrupted and nascent Nrf2 can translocate into the nucleus and bind to the antioxidant response element (ARE) sequences present in enhancer regions of a battery of cytoprotective genes. These genes encode enzymes and other proteins that balance redox homeostasis, detoxify electrophiles and oxidants, enhance drug efflux, alter cellular metabolism, facilitate the recognition, repair or removal of damaged proteins and nucleic acids and can influence networks affecting cell fate decisions ${ }^{7,8,9}$. Several decades of research have also 
shown that the Nrf2 cytoprotective pathway can be predictably induced by low concentrations of sulfhydryl-reactive molecules of many different chemical classes ${ }^{10}$. Interestingly, a majority of these molecules also have a natural and dietary origin. Screening for inducers of Nrf2 signaling in chemical libraries of synthetic or natural products has led to the identification of new chemopreventive agents. Perhaps, not surprisingly, their protective efficacy is often lost in murine models where the gene encoding Nrf2 has been disrupted. Sulforaphane is a prototypical example.

Sulforaphane is - or is amongst - the most potent naturally occurring inducers of Nrf2 signaling, exhibiting efficacy in the high nanomolar range in cell cultures. Its potency may reflect in part a capacity to accumulate in cells as an interchangeable conjugate with glutathione ${ }^{11,12}$. Keap1 is a cysteine-rich protein that serves as the sensor regulating activation of Nrf2 signaling by various chemical classes of anticarcinogens ${ }^{12}$. Using mass spectrometry to detect adducts on recombinant Keap1 treated with sulforaphane, Hong et al. observed that sulforaphane modified multiple Keap1 domains ${ }^{13}$. A follow-up analysis by $\mathrm{Hu}$ et al has determined cysteine 151 to be one of four cysteine residues preferentially modified by sulforaphane ${ }^{14}$. These chemical mapping results are consistent with more recent in vivo observations reported by multiple investigators in which cysteine 151 has also been determined to be the primary target for modification by sulforaphane ${ }^{15}$, 16. As shown in Figure 1, sulforaphane can modify cysteine 151 in Keap1 to 
perturb the association of Cul3 ubiquitin ligase with Keap1, allowing Nrf2 to escape degradation by the proteasome. Thus, Nrf2 is stabilized and translocates into the nucleus to induce the transcription of its target genes such as NADPH:quinone oxidoreductase (NQO1) ${ }^{17}$. In cells in which cysteine 151 of Keap1 has been mutated to serine, nuclear accumulation and subsequent induction of Nrf2 target genes by sulforaphane is severely abrogated ${ }^{18}$.

\section{MOLECULAR TARGETS OF SULFORAPHANE: NOT JUST NRF2}

Extensive evidence supports that sulforaphane is a highly promising chemoprevention agent against multiple diseases - not only a variety of cancers, but also cardiovascular disease ${ }^{19}$, neurodegenerative diseases ${ }^{20}$, autism ${ }^{21}$, and diabetes $^{22}$. Sulforaphane affects many molecular targets in cellular and animal models. In addition to activating the Nrf2-Keap1 signaling pathway, sulforaphane exerts actions such as modulation of some major cytochrome P450 enzymes involved in xenobiotic metabolism. It has been reported that sulforaphane inhibited cytochrome P450 (CYP)1A1 and CYP1A2 enzymes induced by polycyclic aromatic hydrocarbons in HepG2 and MCF7 mammary cancer cells ${ }^{23}$; inhibited CYP1B1 in MCF-10A cells ${ }^{24}$, inhibited CYP2B1/2 in rat hepatocytes ${ }^{17}$; inhibited CYP3A4 in human hepatocytes ${ }^{25}$; however, sulforaphane up-regulated CYP1A2 in MCF-10A cells ${ }^{24}$. The underlying mechanisms of the actions of sulforaphane on cytochrome $\mathrm{P} 450$ expression is unclear, but may relate in part to cross-talk between the Nrf2 and Aryl hydrocarbon receptor (Ahr) pathways ${ }^{26}$. 
Sulforaphane, typically at higher concentrations, also exerts other actions such as enhancement of apoptosis in human breast cancer cell lines ${ }^{27,28,29}$, HT29 human colon cancer cells ${ }^{30}$, prostate cancer cell lines ${ }^{31}$ and human lung cancer cells ${ }^{32}$. Sulforaphane was reported to inhibit mitotic progression and tubulin polymerization in MCF-7 cells ${ }^{33}$. Sulforaphane also induced a synergistic elimination of advanced prostate cancer stem-like cells ${ }^{34}$. By promoting selfrenewal of mesenchymal stem cells and inhibiting adipogenic differentiation, sulforaphane treatment of adipocytes inhibits breast cancer cell migration and tumor formation ${ }^{35}$. Sulforaphane was shown to inhibit breast cancer stem cells ${ }^{36}$. Sulforaphane was reported to modulate estrogen-DNA adducts partially via the Nrf2-Keap1 pathway ${ }^{37}$. However, other signaling pathways may also be important, as it was recently reported that sulforaphane suppresses vascular adhesion molecule- 1 expression in TNF- $\alpha$-stimulated mouse vascular smooth muscle cells, in which the MAPK, NF- $\mathrm{BB}$ and AP-1 signaling pathways are involved $^{38}$.

A target of emerging importance is epigenetic regulation, which mainly refers to stably heritable changes in genetic expression without altering the DNA sequence $^{39}$. The role of bioactive dietary components in the regulation of epigenetics is increasingly gaining much attention. Recently, Kong's group reported that sulforaphane reduced the methylation ratio of the first $15 \mathrm{CpGs}$ of the Nrf2 gene promoter and increased Nrf2 mRNA 
expression in a mouse skin epidermal JB6 cell model. They also reported that sulforaphane decreased the protein expression of DNA methytransferases (DNMTs) and histone deacetylase (HDAC) 1/2/3/4. Their findings suggest that sulforaphane modifies epigenetic function during skin carcinogenesis in part by modulating Nrf2 ${ }^{40}$. Sulforaphane inhibited the expression of DNMTs and methylation in cyclin D2 promoter regions containing c-Myc and multiple Sp1 binding sites, which promote cyclin $\mathrm{D} 2$ transcript levels in $\mathrm{LnCaP}$ prostate cancer cells $^{41}$. Sulforaphane inhibited human telomerase reverse transcriptase (hTERT), the catalytic regulatory subunit of telomerase, and DNMTs in both MCF-7 and MDA-MB-231 human breast cancer cells ${ }^{42}$. In this study, down-regulation of DNMTs in response to sulforaphane induced site-specific $\mathrm{CpG}$ demethylation occurring primarily in the first exon of the hTERT gene thereby facilitating CTCF binding associated with hTERT repression ${ }^{42}$.

Sulforaphane was reported to inhibit HDAC activity in BPH-1, $\mathrm{LnCaP}$ and PC-3 prostate epithelial cells ${ }^{43}$, in HCT116 colon cancer cells ${ }^{44}$ and human embryonic kidney 293 cells $^{44,45}$. Sulforaphane has been found to inhibit HDAC activity not only in vitro, but also in in vivo models. By using wild-type and Apc ${ }^{\text {min }}$ mice, Myzak et al. demonstrated that HDAC inhibition by sulforaphane induces acetylated histones on the promoters of genes such as $P 21$ and $b a x$, and the derepressed genes trigger cell cycle arrest and apoptosis in transformed cells and microadenomas, thereby suppressing polyp formation in the GI tract ${ }^{46}$. By using a 
PC-3 xenograft nude mouse model, Myzak et al. further reported that sulforaphane retarded the growth of prostate cancer PC-3 tumor xenografts by decreasing HDAC activity ${ }^{47}$. In human subjects, a single dose of $68 \mathrm{~g}$ broccoli sprouts inhibited HDAC activity significantly in peripheral blood mononuclear cells (PBMC) 3 and 6 hours following consumption ${ }^{47}$.

\section{THE CRUCIFER - SULFORAPHANE CONNECTION}

Based on findings from epidemiology studies suggesting that frequent consumption of cruciferous vegetables was associated with lower incidence of multiple tumor types, Talalay and colleagues screened extracts of these and other vegetables for bioactive molecules ${ }^{48}$. At this time, Nrf2 had not been identified; however, a small, seemingly co-regulated gene battery including glutathione Stransferases, UDP-glucuronosyl transferases and NQO1 were known to be induced by phenolic antioxidants and other compounds, including isothiocyanates, described as anticarcinogens in vivo. Using induction of NQO1 activity in Hepa 1c1c7 cells as a bioassay, fractionations from broccoli extract were subjected to high performance liquid chromatography and assayed. Sulforaphane, a slightly yellow liquid generated after the evaporation of the major active HPLC fraction was thus discovered and identified. Sulforaphane, [1isothiocyanato-4-(methylsulfinyl)butane; $\mathrm{CH}_{3}-\mathrm{SO}-\left(\mathrm{CH}_{2}\right) 4-\mathrm{N}=\mathrm{C}=\mathrm{S}$ ], containing the $\mathrm{N}=\mathrm{C}=\mathrm{S}$ group, is a phytochemical belonging to a large chemical family of isothiocyanates. Sulforaphane is stored as its relatively stable precursor, 
glucosinolate (glucoraphanin, Figure 2), in a variety of cruciferous vegetables including broccoli, Brussels sprouts, cauliflower, and cabbage ${ }^{49}$. Glucoraphanin is converted to sulforaphane by myrosinase, a $\beta$-thioglucoside glucohydrolase (EC 3.2.3.1), during damage of plant integrity or by hydrolysis by uncharacterized $\beta$ thioglucosidases of the gut microflora ${ }^{50}$. In plants, glucosinolates are spatially separated from myrosinase ${ }^{51}$, which is localized in idioblasts (myrosin cells) scattered throughout most tissues of glucosinolate-generating plants ${ }^{52,53}$. During chewing or chopping processes or as a plant defensive mechanism against pathogens or insects, glucosinolate and myrosinase are released from different cells or subcellular organelles. Following contact, resulting in rapid hydrolysis, glucose is liberated and unstable aglycones are formed that spontaneously rearrange to metabolites such as the isothiocyanate, sulforaphane (Figure 2). With different conditions such as temperature, $\mathrm{pH}$ or presence of $\mathrm{Fe}^{2+}$ the product of glucosinolate-myrosinase reaction is different. At high or neutral $\mathrm{pH}$, isothiocyanates such as sulforaphane will be the primary products of glucosinolate hydrolysis. In contrast, at acidic $\mathrm{pH}$, or in the presence of $\mathrm{Fe}^{2+}$, with the enzyme epithiospecifier protein, the production of a nitrile, which is less bioactive, will be favored $^{54}$.

The highest concentrations of glucosinolates are found in reproductive organs, including dormant and germinating seeds, developing inflorescences, siliques (fruits), followed by young leaves, roots and mature leaves, which is consistent 
with the function of glucosinolate-myrosinase system as defensive mechanism in the plant ${ }^{55,56} .3$-Day-old broccoli sprouts contain 10-100 times higher levels of glucoraphanin than do the mature broccoli ${ }^{57}$. With the virtues of feasibility, safety, effectiveness and low cost, sulforaphane in the milieu of broccoli sprout extracts has attracted extensive interest as a potential effective chemoprevention agent in humans. However, because of the intrinsic simplicity of reductionist approaches, the isolate sulforaphane is almost universally used for studies of mechanism of action and efficacy in animal models.

Abundant evidence indicates that sulforaphane is rapidly absorbed; achieving high absolute bioavailability with oral doses, distributed in different organs, metabolized, and excreted in the urine, principally as the $N$-acetylcysteine (NAC) conjugate - a mercapturic acid (See Figure 2). Following administration of a single oral dose of $50 \mu$ mole sulforaphane to Fisher F344 rats, peak plasma concentrations were observed at $4 \mathrm{~h}$, declined with a half-life of about $2.2 \mathrm{~h}$ and sulforaphane was no longer detected by $24 \mathrm{~h}^{58}$. In Sprague-Dawley rats, after administering a single dose of sulforaphane $(50 \mathrm{mg} / \mathrm{kg}$ ip), $60 \%$ of the dose was eliminated in urine NAC conjugates in $24 \mathrm{~h}^{59}$. Following oral administration of sulforaphane to mice, sulforaphane was detected in all tissues, with the highest concentration in the stomach, second in the bladder; very low levels of sulforaphane were detected in colon, prostate and several other organs ${ }^{60}$. However, in another mouse model, after post-gavage of sulforaphane ( 2 and $6 \mathrm{~h}$ ), 
the highest concentration of sulforaphane was detected in the small intestine, prostate, kidney and lung; the metabolites of sulforaphane were detected in all tissues $^{61}$.

\section{PRECLINICAL STUDIES OF SULFORAPHANE}

As summarized in Table 1, sulforaphane (and in a few cases broccoli sprout extract) have been evaluated as inhibitors of experimental carcinogenesis utilizing chemical carcinogens, genetic models and tumor xenografts. The most dramatic effects occurred during the initiation stage of carcinogenesis; while efficacy in the post-initiation stages of carcinogenesis has also been reported. The initial report of cancer chemopreventive efficacy of sulforaphane was in a model of mammary tumor development in female Sprague-Dawley rats treated with the carcinogen 7 , 12-dimethyl-benzanthracene (DMBA $)^{62}$. In this study, after administration of sulforaphane by gavage ( 75 or $150 \mu \mathrm{mol}$ per day for 5 days) around the time of exposure to DMBA, the incidence, multiplicity, and weight of mammary tumors were significantly reduced, and their development was delayed. This model was used later for evaluation of the anti-carcinogenic action of an extract of 3-day old broccoli sprouts, which contains the precursor of sulforaphane, glucoraphanin. Consistent with the findings of sulforaphane, the extract of broccoli sprouts markedly reduced the incidence and multiplicity of mammary tumors ${ }^{57}$. A pharmacodynamic study in Sprague Dawley rats demonstrated that sulforaphane 
could induce NQO1 transcripts, protein and activity to a substantive degree in the mammary epithelium ${ }^{63}$, consistent with the role of $\mathrm{Nrf} 2$ in its protective action. Studies in murine models provide more direct evidence for the efficacy of sulforaphane across stages of carcinogenesis and for a direct role of Nrf2 in the protective actions of sulforaphane. In SKH-1 hairless, high-risk mice, ultraviolet (UV)-radiation-induced skin carcinogenesis was substantially inhibited by topical administration of a broccoli sprout extract containing $1 \mu$ mole sulforaphane: incidence and multiplicity were reduced by 50\% in the treatment group compared with controls ${ }^{64}$. Also in SKH-1 mice, sulforaphane treatment effectively reduced the multiplicity and tumor burden of squamous cell carcinomas induced by UVB exposure $^{65}$. Accumulating evidence indicates that sulforaphane not only inhibits skin carcinogenesis in the initiation stage, but also significantly retards skin tumorigenesis during the promotion stage. In the classic two-stage mouse skin carcinogenesis model, by which tumors are initiated by DMBA and promoted by repeated dosing with 12 - $O$-tetradecanoylphorbol 13 -acetate (TPA), the results showed that sulforaphane inhibited incidence and multiplicity of tumors during the promotion stage instead of the initiation stage ${ }^{66}$. However, Xu et al. ${ }^{67}$ have observed that pre-treatment with sulforaphane prior to initiation with DMBA and subsequent promotion with TPA reduces the incidence of skin tumors, when compared with the vehicle-pretreated group. Interestingly, no chemoprotective effect was observed with sulforaphane pre-treatment when Nrf2-disrupted mice 
were used in this study. This result supports the concept that the Keap1-Nrf2 pathway plays an essential role in the mechanism of action of sulforaphane against skin cancer. Earlier studies had demonstrated that sulforaphane effectively reduced tumor multiplicity of benzo[a]pyrene-evoked forestomach tumors in wild-type, but not Nrf2-disrupted mice ${ }^{68}$.

Further, sulforaphane has been shown to exert anticancer effects against a variety of cancer types in xenograft models. Sulforaphane treatment significantly inhibited growth of xenografts of human prostate cancer PC-3 cancer cells ${ }^{69}$. Intraperitoneal treatment of sulforaphane significantly inhibited the growth of LM8 osteosarcoma xenografts in Balb/C nude mice ${ }^{70}$. Subcutaneous injection of sulforaphane significantly decreased tumor weight and volume of A549 lung cancer xenografts in athymic Ncr-nu/nu nude mice ${ }^{71}$. Sulforaphane also has been found to significantly inhibit tumor volumes after implantation of B16 melanoma cells in $\mathrm{C} 57 \mathrm{Bl} / 6$ mice $^{72}$.

\section{CLINICAL STUDIES WITH SULFORAPHANE}

Extensive work by Talalay and colleagues has characterized the pharmacokinetics and safety in humans of ingestion of sulforaphane-rich (SFR) or glucoraphaninrich (GRR) hot water extracts prepared from broccoli sprouts ${ }^{73,74,75}$. Typically, freeze-dried standardized sprout extracts from specifically selected cultivars and seed sources grown in a prescribed manner have been utilized to provide consistency of preparations across multiple studies. First and foremost, these 
studies have established the safety of these GRR and SFR preparations. Dose limiting factors center on taste, gastric irritation and flatulence. Second, they have demonstrated a linear uptake and elimination of sulforaphane following administration of a wide range of doses as a SFR beverage. Third, bioavailability of sulforaphane was substantially better when administered as a SFR versus a GRR beverage. This latter result points to a limited capacity for the microbial $\beta$ thioglucosidases of the human gut to catalyze the conversion of glucoraphanin to sulforaphane. Subsequently, dozens of clinical trials have been underway or completed utilizing broccoli sprout preparations, as indicated by a review of the ClinicalTrials.gov website. Summarized below and in Table 2 are key questions and findings addressed in some of these trials.

In a pilot breast cancer prevention study, a single oral dose of a broccoli sprout preparation containing $200 \mu \mathrm{mol}$ of sulforaphane was given to eight healthy women undergoing reduction mammoplasty. The goal was to assess whether or to what extent sulforaphane reached potential at-risk cells in the mammary gland. Total isothiocyantes in lieu of sulforaphane were measured: there was a 40-fold increase in urinary and 90-fold increase in plasma content of isothiocyanates ${ }^{63}$. Concentrations of $2 \mu \mathrm{M}$ isothiocyanate were measured in the mammary tissue. Coupled with earlier studies in human mammosphere cultures or mammary epithelial cell lines in which sulforaphane induces Nrf2 target genes ${ }^{76}$ and diminishes the formation of estrogen-DNA adducts ${ }^{29}$, future clinical trials to 
address the protective function of broccoli sprout preparation against breast cancer risk is plausible.

Other studies have addressed whether sulforaphane, in the form of broccoli sprout extracts, could modulate the metabolism and disposition of environmental carcinogens. Towards that end, a series of studies have been undertaken in Qidong, China, a region known as a "hot-spot" for hepatocellular carcinoma because of co-exposures to hepatitis B virus and aflatoxins. In 2003, a beverage formed from hot water infusions of 3-day old broccoli sprouts grown on site, containing defined concentrations of glucoraphanin as the stable precursor of the sulforaphane, was evaluated for its ability to alter the disposition of aflatoxin. Exposures to aflatoxin, common in this community, likely arose from fungal contamination of their dietary staples. In this clinical study, 200 healthy adults drank beverages containing either 400 or $<3 \mu$ mole glucoraphanin nightly for 2 weeks. Urinary levels of aflatoxin- $\mathrm{N}^{7}$-guanine, formed from depurination of the primary hepatic DNA adduct, were not statistically different between the two intervention arms. However, measurement of urinary levels of sulforaphane metabolites indicated striking interindividual differences in bioavailability. This outcome may reflect individual differences in the rates of hydrolysis of glucoraphanin to sulforaphane by the intestinal microflora of the study participants. Accounting for this variability, a significant inverse association was observed for excretion of total sulforaphane metabolites and aflatoxin- $N^{7}$-guanine 
adducts in individuals receiving broccoli sprout glucosinolates ${ }^{77}$. This preliminary study illustrated the potential use of an inexpensive, easily implemented, foodbased method for secondary prevention in a population at high risk for aflatoxin exposures. In the intervening decade from this trial, the efficacy of primary prevention, an economic policy-driven dietary shift away from aflatoxincontaminated dietary staples, has led to declining age-standardized rates of liver cancer in this region ${ }^{78}$.

An emerging problem in this region of China is outdoor air pollution. Analysis of urine samples for levels of phenanthrene tetraol, a metabolite of the polycyclic aromatic hydrocarbon and air pollutant phenanthrene, from samples collected in the 2003 Qidong study indicated levels 4-5 times higher than measured in urine samples collected from urban residents of Minneapolis - St. Paul, Minnesota at the same time ${ }^{77}$. As seen with the aflatoxin biomarker, there was a significant inverse association between levels of excretion of phenanthrene tetraol and sulforaphane metabolites.

Some of the several challenges in the design of clinical chemoprevention trials are selection of an adequate dose, type of formulation, and dose schedule of the intervention agent. In a 2009 cross-over clinical trial, in which fifty healthy subjects were recruited to take two broccoli sprout-derived beverages: one glucoraphanin-rich (GRR) and the other sulforaphane-rich (SFR), the bioavailability and tolerability of sulforaphane from these two beverages were 
compared. After a 5-day run-in period, a 7-day administration of one beverage, a 5-day washout period, and a 7-day administration of the opposite intervention beverage, the results showed that urinary excretion of sulforaphane and its metabolites was substantially greater with the SFR $($ mean $=70 \%)$ than with GRR ( mean $=5 \%)$ beverages; while the elimination rates were considerably slower with $\mathrm{GRR}^{79}$. Urinary levels of phenanthrene tetraol remained high in these 2009 Qidong samples ${ }^{80}$. Therefore, urinary excretion of the mercapturic acids of the air-borne toxins acrolein, crotonaldehyde, ethylene oxide and benzene were also measured in urine samples from both pre- and post-interventions using liquid chromatography tandem mass spectrometry. Statistically significant increases of $20-50 \%$ in the levels of excretion of glutathione-derived conjugates of acrolein, crotonaldehyde and benzene were seen in individuals receiving SFR, GRR or both compared with their pre-intervention baseline values. No significant differences were seen between the effects of SFR versus GRR on the pollutant biomarker levels ${ }^{80}$. In a recently completed 12 -week placebo-controlled, randomized clinical trial, in which 291 participants from Qidong were provided a broccoli sprout beverage containing both $40 \mu$ mole sulforaphane and $600 \mu$ mole glucoraphanin, the urinary levels of the mercapturic acids of the air pollutants, benzene and acrolein were measured and used as biomarkers of health risk. The detoxification of these airborne pollutants was enhanced by the broccoli sprouts beverage. The levels of 
excretion of the glutathione-derived conjugates of benzene (61\%) and acrolein (23\%) were significantly higher in the participants who received the broccoli sprout beverage compared with placebo. This increase in pollutant-mercapturic

acid excretion was rapid and sustained throughout the intervention ${ }^{81}$. Using the GRR and SFR blend of broccoli sprout extract provided a more consistent bioavailability of sulforaphane to the study participants. On average, 50-60 $\mu$ mole of sulforaphane metabolites were excreted in urine in the $24 \mathrm{~h}$ period subsequent to dosing. Sulforaphane-N-acetylcysteine (80\%-81\%), sulforaphane-cysteine $(12 \%-14 \%)$, and free sulforaphane $(5-7 \%)$ were the major urinary metabolites, while the other glutathione-derived conjugates accounted for $<1 \%{ }^{81}$. Overall, the study provided strong evidence that broccoli sprout beverage can modulate the disposition of environmental carcinogens and toxins. The role of Nrf2 in these actions is inferred, but not established as the study noted influences of polymorphisms in GST isoforms and in the promoter region of NRF2 itself on the rates of detoxication of benzene.

\section{CONCLUSIONS}

Prevention trials of whole foods or simple extracts offer prospects for reducing an expanding global burden of cancer effectively with minimal cost, in contrast to promising isolated phytochemicals or pharmaceuticals ${ }^{82}$. Sulforaphane- or glucoraphanin-rich broccoli sprout extracts provide one avenue towards this end. Clinical trial results demonstrating modulation of exposure (and risk) biomarkers 
for environmental carcinogens, notably aflatoxins and air pollutants, offer a prospect of impact. A recent placebo-controlled, double-blind randomized trial in which daily oral doses of dietary sulforaphane over 18 weeks demonstrated substantial improvements in markers of autism spectrum disorder further highlights the possible impact on conditions other than cancer ${ }^{13}$. Together with other clinical trial results heralding beneficial actions of drugs known to affect Nrf2 signaling, notably dimethylfumarate as an FDA-approved treatment for multiple sclerosis ${ }^{83}$ and bardoxolone methyl for chronic kidney disease ${ }^{84}$, there is optimism that the overall strategies are moving forward. Further refinements in formulation, consistency in bioavailability, development of informative pharmacodynamic biomarkers and broadened demonstrations of efficacy, while maintaining frugality, will be required to enhance the use of food-based approaches to chemoprevention.

References

(1) Colditz, G. A.; Wolin, K. Y.; Gehlert, S. Applying What We Know to Accelerate Cancer Prevention. Sci. Transl. Med. 2012, 4, 127rv4.

(2) Surh, Y. J. Cancer Chemoprevention With Dietary Phytochemicals. Nat. Rev. Cancer 2003, 3, 768-780.

(3) Lee, J. H.; Khor, T. O.; Shu, L.; Su, Z. Y.; Fuentes, F.; Kong, A. N. Dietary Phytochemicals and Cancer Prevention: Nrf2 Signaling, Epigenetics, and Cell Death Mechanisms in Blocking Cancer Initiation and Progression. Pharmacol. Ther. 2013, 137, 153-171. 
(4) Thakur, V. S.; Deb, G.; Babcook, M. A.; Gupta, S. Plant Phytochemicals As Epigenetic Modulators: Role in Cancer Chemoprevention. AAPS. J. 2014, 16, 151-163.

(5) Itoh, K.; Wakabayashi, N.; Katoh, Y.; Ishii, T.; Igarashi, K.; Engel, J. D.; Yamamoto, M. Keap1 Represses Nuclear Activation of Antioxidant Responsive Elements by Nrf2 Through Binding to the Amino-Terminal Neh2 Domain. Genes Dev. 1999, 13, 76-86.

(6) Zhang, D. D.; Lo, S. C.; Cross, J. V.; Templeton, D. J.; Hannink, M. Keap1 Is a Redox-Regulated Substrate Adaptor Protein for a Cul3-Dependent Ubiquitin Ligase Complex. Mol. Cell Biol. 2004, 24, 10941-10953.

(7) Yates, M. S.; Tran, Q. T.; Dolan, P. M.; Osburn, W. O.; Shin, S.; McCulloch, C. C.; Silkworth, J. B.; Taguchi, K.; Yamamoto, M.; Williams, C. R.; Liby, K. T.; Sporn, M. B.; Sutter, T. R.; Kensler, T. W. Genetic Versus Chemoprotective Activation of Nrf2 Signaling: Overlapping Yet Distinct Gene Expression Profiles Between Keap1 Knockout and Triterpenoid-Treated Mice. Carcinogenesis 2009, 30, 1024-1031.

(8) Osburn, W. O.; Yates, M. S.; Dolan, P. D.; Chen, S.; Liby, K. T.; Sporn, M. B.; Taguchi, K.; Yamamoto, M.; Kensler, T. W. Genetic or Pharmacologic Amplification of Nrf2 Signaling Inhibits Acute Inflammatory Liver Injury in Mice. Toxicol. Sci. 2008, 104, 218-227.

(9) Slocum, S. L.; Kensler, T. W. Nrf2: Control of Sensitivity to Carcinogens. Arch. Toxicol. 2011, 85, 273-284. 
(10) Baird, L.; Dinkova-Kostova, A. T. The Cytoprotective Role of the Keap1-Nrf2 Pathway. Arch. Toxicol. 2011, 85, 241-272.

(11) Zhang, Y. Role of Glutathione in the Accumulation of Anticarcinogenic Isothiocyanates and Their Glutathione Conjugates by Murine Hepatoma Cells. Carcinogenesis 2000, 21, 1175-1182.

(12) Dinkova-Kostova, A. T.; Holtzclaw, W. D.; Cole, R. N.; Itoh, K.;

Wakabayashi, N.; Katoh, Y.; Yamamoto, M.; Talalay, P. Direct Evidence That Sulfhydryl Groups of Keap1 Are the Sensors Regulating Induction of Phase 2 Enzymes That Protect Against Carcinogens and Oxidants. Proc. Natl. Acad. Sci. U. S. A 2002, 99, 11908-11913.

(13) Hong, F.; Freeman, M. L.; Liebler, D. C. Identification of Sensor Cysteines in Human Keap1 Modified by the Cancer Chemopreventive Agent Sulforaphane. Chem. Res. Toxicol. 2005, 18, 1917-1926.

(14) Hu, C.; Eggler, A. L.; Mesecar, A. D.; van Breemen, R. B. Modification of Keap1 Cysteine Residues by Sulforaphane. Chem. Res. Toxicol. 2011, 24, 515521.

(15) McMahon, M.; Lamont, D. J.; Beattie, K. A.; Hayes, J. D. Keap1 Perceives Stress Via Three Sensors for the Endogenous Signaling Molecules Nitric Oxide, Zinc, and Alkenals. Proc. Natl. Acad. Sci. U. S. A 2010, 107, 1883818843.

(16) Kobayashi, M.; Li, L.; Iwamoto, N.; Nakajima-Takagi, Y.; Kaneko, H.; Nakayama, Y.; Eguchi, M.; Wada, Y.; Kumagai, Y.; Yamamoto, M. The Antioxidant Defense System Keap1-Nrf2 Comprises a Multiple Sensing 
Mechanism for Responding to a Wide Range of Chemical Compounds. Mol. Cell Biol. 2009, 29, 493-502.

(17) Hu, R.; Xu, C.; Shen, G.; Jain, M. R.; Khor, T. O.; Gopalkrishnan, A.; Lin, W.; Reddy, B.; Chan, J. Y.; Kong, A. N. Gene Expression Profiles Induced by Cancer Chemopreventive Isothiocyanate Sulforaphane in the Liver of C57BL/6J Mice and C57BL/6J/Nrf2 (-/-) Mice. Cancer Lett. 2006, 243, 170192.

(18) Takaya, K.; Suzuki, T.; Motohashi, H.; Onodera, K.; Satomi, S.; Kensler, T. W.; Yamamoto, M. Validation of the Multiple Sensor Mechanism of the Keap1-Nrf2 System. Free Radic. Biol. Med. 2012, 53, 817-827.

(19) Evans, P. C. The Influence of Sulforaphane on Vascular Health and Its Relevance to Nutritional Approaches to Prevent Cardiovascular Disease. EPMA. J. 2011, 2, 9-14.

(20) Tarozzi, A.; Angeloni, C.; Malaguti, M.; Morroni, F.; Hrelia, S.; Hrelia, P. Sulforaphane As a Potential Protective Phytochemical Against Neurodegenerative Diseases. Oxid. Med. Cell Longev. 2013, 2013, 415078.

(21) Singh, K.; Connors, S. L.; Macklin, E. A.; Smith, K. D.; Fahey, J. W.; Talalay, P.; Zimmerman, A. W. Sulforaphane Treatment of Autism Spectrum Disorder (ASD). Proc. Natl. Acad. Sci. U. S. A 2014, 111, 15550-15555.

(22) Wang, Y.; Zhang, Z.; Sun, W.; Tan, Y.; Liu, Y.; Zheng, Y.; Liu, Q.; Cai, L.; Sun, J. Sulforaphane Attenuation of Type 2 Diabetes-Induced Aortic Damage Was Associated With the Upregulation of Nrf2 Expression and Function. Oxid. Med. Cell Longev. 2014, 2014, 123963. 
(23) Skupinska, K.; Misiewicz-Krzeminska, I.; Stypulkowski, R.; Lubelska, K.; Kasprzycka-Guttman, T. Sulforaphane and Its Analogues Inhibit CYP1A1 and CYP1A2 Activity Induced by Benzo[a]Pyrene. J. Biochem. Mol. Toxicol. 2009, 23, 18-28.

(24) Licznerska, B.; Szaefer, H.; Matuszak, I.; Murias, M.; Baer-Dubowska, W. Modulating Potential of L-Sulforaphane in the Expression of Cytochrome P450 to Identify Potential Targets for Breast Cancer Chemoprevention and Therapy Using Breast Cell Lines. Phytother. Res. 2014.

(25) Maheo, K.; Morel, F.; Langouet, S.; Kramer, H.; Le, F. E.; Ketterer, B.; Guillouzo, A. Inhibition of Cytochromes P-450 and Induction of Glutathione S-Transferases by Sulforaphane in Primary Human and Rat Hepatocytes. Cancer Res. 1997, 57, 3649-3652.

(26) Wakabayashi, N.; Slocum, S. L.; Skoko, J. J.; Shin, S.; Kensler, T. W. When NRF2 Talks, Who's Listening? Antioxid. Redox. Signal. 2010, 13, 1649-1663.

(27) Misiewicz, I.; Kozar, A.; Skupinska, K.; Kowalska, E.; Lubinski, J.; Kasprzycka-Guttman, T. Inhibition of Cell Cycle and Induction of Apoptosis by Sulforaphane in Cell Lines Carrying Various Inherited BRCA1 Mutations. Oncol. Rep. 2005, 13, 659-665.

(28) Kanematsu, S.; Uehara, N.; Miki, H.; Yoshizawa, K.; Kawanaka, A.; Yuri, T.; Tsubura, A. Autophagy Inhibition Enhances Sulforaphane-Induced Apoptosis in Human Breast Cancer Cells. Anticancer Res. 2010, 30, 3381-3390. 
(29) Pledgie-Tracy, A.; Sobolewski, M. D.; Davidson, N. E. Sulforaphane Induces Cell Type-Specific Apoptosis in Human Breast Cancer Cell Lines. Mol. Cancer Ther. 2007, 6, 1013-1021.

(30) Gamet-Payrastre, L.; Li, P.; Lumeau, S.; Cassar, G.; Dupont, M. A.; Chevolleau, S.; Gasc, N.; Tulliez, J.; Terce, F. Sulforaphane, a Naturally Occurring Isothiocyanate, Induces Cell Cycle Arrest and Apoptosis in HT29 Human Colon Cancer Cells. Cancer Res. 2000, 60, 1426-1433.

(31) Choi, S.; Lew, K. L.; Xiao, H.; Herman-Antosiewicz, A.; Xiao, D.; Brown, C. K.; Singh, S. V. D,L-Sulforaphane-Induced Cell Death in Human Prostate Cancer Cells Is Regulated by Inhibitor of Apoptosis Family Proteins and Apaf1. Carcinogenesis 2007, 28, 151-162.

(32) Liang, H.; Lai, B.; Yuan, Q. Sulforaphane Induces Cell-Cycle Arrest and Apoptosis in Cultured Human Lung Adenocarcinoma LTEP-A2 Cells and Retards Growth of LTEP-A2 Xenografts in Vivo. J. Nat. Prod. 2008, 71, 19111914.

(33) Jackson, S. J.; Singletary, K. W. Sulforaphane Inhibits Human MCF-7 Mammary Cancer Cell Mitotic Progression and Tubulin Polymerization. J. Nutr. 2004, 134, 2229-2236.

(34) Labsch, S.; Liu, L.; Bauer, N.; Zhang, Y.; Aleksandrowicz, E.; Gladkich, J.; Schonsiegel, F.; Herr, I. Sulforaphane and TRAIL Induce a Synergistic Elimination of Advanced Prostate Cancer Stem-Like Cells. Int. J. Oncol. 2014, 44, 1470-1480. 
(35) Li, Q.; Xia, J.; Yao, Y.; Gong, D. W.; Shi, H.; Zhou, Q. Sulforaphane Inhibits Mammary Adipogenesis by Targeting Adipose Mesenchymal Stem Cells. Breast Cancer Res. Treat. 2013, 141, 317-324.

(36) Li, Y.; Zhang, T.; Korkaya, H.; Liu, S.; Lee, H. F.; Newman, B.; Yu, Y.; Clouthier, S. G.; Schwartz, S. J.; Wicha, M. S.; Sun, D. Sulforaphane, a Dietary Component of Broccoli/Broccoli Sprouts, Inhibits Breast Cancer Stem Cells. Clin. Cancer Res. 2010, 16, 2580-2590.

(37) Yang, L.; Zahid, M.; Liao, Y.; Rogan, E. G.; Cavalieri, E. L.; Davidson, N. E.; Yager, J. D.; Visvanathan, K.; Groopman, J. D.; Kensler, T. W. Reduced Formation of Depurinating Estrogen-DNA Adducts by Sulforaphane or KEAP1 Disruption in Human Mammary Epithelial MCF-10A Cells. Carcinogenesis 2013, 34, 2587-2592.

(38) Kim, J. Y.; Park, H. J.; Um, S. H.; Sohn, E. H.; Kim, B. O.; Moon, E. Y.; Rhee, D. K.; Pyo, S. Sulforaphane Suppresses Vascular Adhesion Molecule-1 Expression in TNF-Alpha-Stimulated Mouse Vascular Smooth Muscle Cells: Involvement of the MAPK, NF-KappaB and AP-1 Signaling Pathways. Vascul. Pharmacol. 2012, 56, 131-141.

(39) Waddington, C. H. The Epigenotype. 1942. Int. J. Epidemiol. 2012, 41, 10-13.

(40) Su, Z. Y.; Zhang, C.; Lee, J. H.; Shu, L.; Wu, T. Y.; Khor, T. O.; Conney, A. H.; Lu, Y. P.; Kong, A. N. Requirement and Epigenetics Reprogramming of Nrf2 in Suppression of Tumor Promoter TPA-Induced Mouse Skin Cell Transformation by Sulforaphane. Cancer Prev. Res. (Phila) 2014, 7, 319-329. 
(41) Hsu, A.; Wong, C. P.; Yu, Z.; Williams, D. E.; Dashwood, R. H.; Ho, E. Promoter De-Methylation of Cyclin D2 by Sulforaphane in Prostate Cancer Cells. Clin. Epigenetics. 2011, 3, 3.

(42) Meeran, S. M.; Patel, S. N.; Tollefsbol, T. O. Sulforaphane Causes Epigenetic Repression of HTERT Expression in Human Breast Cancer Cell Lines. PLoS. One. 2010, 5, e11457.

(43) Myzak, M. C.; Hardin, K.; Wang, R.; Dashwood, R. H.; Ho, E. Sulforaphane Inhibits Histone Deacetylase Activity in BPH-1, LnCaP and PC-3 Prostate Epithelial Cells. Carcinogenesis 2006, 27, 811-819.

(44) Rajendran, P.; Kidane, A. I.; Yu, T. W.; Dashwood, W. M.; Bisson, W. H.; Lohr, C. V.; Ho, E.; Williams, D. E.; Dashwood, R. H. HDAC Turnover, CtIP Acetylation and Dysregulated DNA Damage Signaling in Colon Cancer Cells Treated With Sulforaphane and Related Dietary Isothiocyanates. Epigenetics. 2013, 8, 612-623.

(45) Myzak, M. C.; Karplus, P. A.; Chung, F. L.; Dashwood, R. H. A Novel Mechanism of Chemoprotection by Sulforaphane: Inhibition of Histone Deacetylase. Cancer Res. 2004, 64, 5767-5774.

(46) Myzak, M. C.; Dashwood, W. M.; Orner, G. A.; Ho, E.; Dashwood, R. H. Sulforaphane Inhibits Histone Deacetylase in Vivo and Suppresses Tumorigenesis in Apc-Minus Mice. FASEB J. 2006, 20, 506-508.

(47) Myzak, M. C.; Tong, P.; Dashwood, W. M.; Dashwood, R. H.; Ho, E. Sulforaphane Retards the Growth of Human PC-3 Xenografts and Inhibits 
HDAC Activity in Human Subjects. Exp. Biol. Med. (Maywood. ) 2007, 232, 227-234.

(48) Zhang, Y.; Talalay, P.; Cho, C. G.; Posner, G. H. A Major Inducer of Anticarcinogenic Protective Enzymes From Broccoli: Isolation and Elucidation of Structure. Proc. Natl. Acad. Sci. U. S. A 1992, 89, 2399-2403.

(49) Fahey, J. W.; Zhang, Y.; Talalay, P. Broccoli Sprouts: an Exceptionally Rich Source of Inducers of Enzymes That Protect Against Chemical Carcinogens. Proc. Natl. Acad. Sci. U. S. A 1997, 94, 10367-10372.

(50) Shapiro, T. A.; Fahey, J. W.; Wade, K. L.; Stephenson, K. K.; Talalay, P. Chemoprotective Glucosinolates and Isothiocyanates of Broccoli Sprouts: Metabolism and Excretion in Humans. Cancer Epidemiol. Biomarkers Prev. 2001, 10, 501-508.

(51) Kelly, P. J.; Bones, A.; Rossiter, J. T. Sub-Cellular Immunolocalization of the Glucosinolate Sinigrin in Seedlings of Brassica Juncea. Planta 1998, 206, 370377.

(52) Andreasson, E.; Bolt, J. L.; Hoglund, A. S.; Rask, L.; Meijer, J. Different Myrosinase and Idioblast Distribution in Arabidopsis and Brassica Napus. Plant Physiol 2001, 127, 1750-1763.

(53) Husebye, H.; Chadchawan, S.; Winge, P.; Thangstad, O. P.; Bones, A. M. Guard Cell- and Phloem Idioblast-Specific Expression of Thioglucoside Glucohydrolase 1 (Myrosinase) in Arabidopsis. Plant Physiol 2002, 128, 11801188. 
(54) Hayes, J. D.; Kelleher, M. O.; Eggleston, I. M. The Cancer Chemopreventive Actions of Phytochemicals Derived From Glucosinolates. Eur. J. Nutr. 2008, 47 Suppl 2, 73-88.

(55) Brown, P. D.; Tokuhisa, J. G.; Reichelt, M.; Gershenzon, J. Variation of Glucosinolate Accumulation Among Different Organs and Developmental Stages of Arabidopsis Thaliana. Phytochemistry 2003, 62, 471-481.

(56) Petersen, B. L.; Chen, S.; Hansen, C. H.; Olsen, C. E.; Halkier, B. A. Composition and Content of Glucosinolates in Developing Arabidopsis Thaliana. Planta 2002, 214, 562-571.

(57) Fahey, J. W.; Zhang, Y.; Talalay, P. Broccoli Sprouts: an Exceptionally Rich Source of Inducers of Enzymes That Protect Against Chemical Carcinogens. Proc. Natl. Acad. Sci. U. S. A 1997, 94, 10367-10372.

(58) Hu, R.; Hebbar, V.; Kim, B. R.; Chen, C.; Winnik, B.; Buckley, B.; Soteropoulos, P.; Tolias, P.; Hart, R. P.; Kong, A. N. In Vivo Pharmacokinetics and Regulation of Gene Expression Profiles by Isothiocyanate Sulforaphane in the Rat. J. Pharmacol. Exp. Ther. 2004, 310, 263-271.

(59) Kassahun, K.; Davis, M.; Hu, P.; Martin, B.; Baillie, T. Biotransformation of the Naturally Occurring Isothiocyanate Sulforaphane in the Rat: Identification of Phase I Metabolites and Glutathione Conjugates. Chem. Res. Toxicol. 1997, 10, 1228-1233.

(60) Veeranki, O. L.; Bhattacharya, A.; Marshall, J. R.; Zhang, Y. Organ-Specific Exposure and Response to Sulforaphane, a Key Chemopreventive Ingredient in Broccoli: Implications for Cancer Prevention. Br. J. Nutr. 2013, 109, 25-32. 
(61) Clarke, J. D.; Hsu, A.; Williams, D. E.; Dashwood, R. H.; Stevens, J. F.; Yamamoto, M.; Ho, E. Metabolism and Tissue Distribution of Sulforaphane in Nrf2 Knockout and Wild-Type Mice. Pharm. Res. 2011, 28, 3171-3179.

(62) Zhang, Y.; Kensler, T. W.; Cho, C. G.; Posner, G. H.; Talalay, P. Anticarcinogenic Activities of Sulforaphane and Structurally Related Synthetic Norbornyl Isothiocyanates. Proc. Natl. Acad. Sci. U. S. A 1994, 91, 3147-3150.

(63) Cornblatt, B. S.; Ye, L.; Dinkova-Kostova, A. T.; Erb, M.; Fahey, J. W.; Singh, N. K.; Chen, M. S.; Stierer, T.; Garrett-Mayer, E.; Argani, P.; Davidson, N. E.; Talalay, P.; Kensler, T. W.; Visvanathan, K. Preclinical and Clinical Evaluation of Sulforaphane for Chemoprevention in the Breast. Carcinogenesis 2007, 28, 1485-1490.

(64) Dinkova-Kostova, A. T.; Jenkins, S. N.; Fahey, J. W.; Ye, L.; Wehage, S. L.; Liby, K. T.; Stephenson, K. K.; Wade, K. L.; Talalay, P. Protection Against UV-Light-Induced Skin Carcinogenesis in SKH-1 High-Risk Mice by Sulforaphane-Containing Broccoli Sprout Extracts. Cancer Lett. 2006, 240, 243-252.

(65) Dickinson, S. E.; Melton, T. F.; Olson, E. R.; Zhang, J.; Saboda, K.; Bowden, G. T. Inhibition of Activator Protein-1 by Sulforaphane Involves Interaction With Cysteine in the CFos DNA-Binding Domain: Implications for Chemoprevention of UVB-Induced Skin Cancer. Cancer Res. 2009, 69, 71037110. 
(66) Gills, J. J.; Jeffery, E. H.; Matusheski, N. V.; Moon, R. C.; Lantvit, D. D.; Pezzuto, J. M. Sulforaphane Prevents Mouse Skin Tumorigenesis During the Stage of Promotion. Cancer Lett. 2006, 236, 72-79.

(67) Xu, C.; Huang, M. T.; Shen, G.; Yuan, X.; Lin, W.; Khor, T. O.; Conney, A. H.; Kong, A. N. Inhibition of 7,12-Dimethylbenz(a)Anthracene-Induced Skin Tumorigenesis in C57BL/6 Mice by Sulforaphane Is Mediated by Nuclear Factor E2-Related Factor 2. Cancer Res. 2006, 66, 8293-8296.

(68) Fahey, J. W.; Haristoy, X.; Dolan, P. M.; Kensler, T. W.; Scholtus, I.;

Stephenson, K. K.; Talalay, P.; Lozniewski, A. Sulforaphane Inhibits Extracellular, Intracellular, and Antibiotic-Resistant Strains of Helicobacter Pylori and Prevents Benzo[a]Pyrene-Induced Stomach Tumors. Proc. Natl. Acad. Sci. U. S. A 2002, 99, 7610-7615.

(69) Singh, A. V.; Xiao, D.; Lew, K. L.; Dhir, R.; Singh, S. V. Sulforaphane Induces Caspase-Mediated Apoptosis in Cultured PC-3 Human Prostate Cancer Cells and Retards Growth of PC-3 Xenografts in Vivo. Carcinogenesis 2004, $25,83-90$.

(70) Matsui, T. A.; Murata, H.; Sakabe, T.; Sowa, Y.; Horie, N.; Nakanishi, R.; Sakai, T.; Kubo, T. Sulforaphane Induces Cell Cycle Arrest and Apoptosis in Murine Osteosarcoma Cells in Vitro and Inhibits Tumor Growth in Vivo. Oncol. Rep. 2007, 18, 1263-1268.

(71) Kombairaju, P.; Ma, J.; Thimmulappa, R. K.; Yan, S. G.; Gabrielson, E.; Singh, A.; Biswal, S. Prolonged Sulforaphane Treatment Does Not Enhance 
Tumorigenesis in Oncogenic K-Ras and Xenograft Mouse Models of Lung Cancer. J. Carcinog. 2012, 11, 8.

(72) Do, D. P.; Pai, S. B.; Rizvi, S. A.; D'Souza, M. J. Development of Sulforaphane-Encapsulated Microspheres for Cancer Epigenetic Therapy. Int. J. Pharm. 2010, 386, 114-121.

(73) Shapiro, T. A.; Fahey, J. W.; Wade, K. L.; Stephenson, K. K.; Talalay, P. Human Metabolism and Excretion of Cancer Chemoprotective Glucosinolates and Isothiocyanates of Cruciferous Vegetables. Cancer Epidemiol. Biomarkers Prev. 1998, 7, 1091-1100.

(74) Shapiro, T. A.; Fahey, J. W.; Dinkova-Kostova, A. T.; Holtzclaw, W. D.; Stephenson, K. K.; Wade, K. L.; Ye, L.; Talalay, P. Safety, Tolerance, and Metabolism of Broccoli Sprout Glucosinolates and Isothiocyanates: a Clinical Phase I Study. Nutr. Cancer 2006, 55, 53-62.

(75) Ye, L.; Dinkova-Kostova, A. T.; Wade, K. L.; Zhang, Y.; Shapiro, T. A.; Talalay, P. Quantitative Determination of Dithiocarbamates in Human Plasma, Serum, Erythrocytes and Urine: Pharmacokinetics of Broccoli Sprout Isothiocyanates in Humans. Clin. Chim. Acta 2002, 316, $43-53$.

(76) Agyeman, A. S.; Chaerkady, R.; Shaw, P. G.; Davidson, N. E.; Visvanathan, K.; Pandey, A.; Kensler, T. W. Transcriptomic and Proteomic Profiling of KEAP1 Disrupted and Sulforaphane-Treated Human Breast Epithelial Cells Reveals Common Expression Profiles. Breast Cancer Res. Treat. 2012, 132, 175-187. 
(77) Kensler, T. W.; Chen, J. G.; Egner, P. A.; Fahey, J. W.; Jacobson, L. P.; Stephenson, K. K.; Ye, L.; Coady, J. L.; Wang, J. B.; Wu, Y.; Sun, Y.; Zhang, Q. N.; Zhang, B. C.; Zhu, Y. R.; Qian, G. S.; Carmella, S. G.; Hecht, S. S.; Benning, L.; Gange, S. J.; Groopman, J. D.; Talalay, P. Effects of Glucosinolate-Rich Broccoli Sprouts on Urinary Levels of Aflatoxin-DNA Adducts and Phenanthrene Tetraols in a Randomized Clinical Trial in He Zuo Township, Qidong, People's Republic of China. Cancer Epidemiol. Biomarkers Prev. 2005, 14, 2605-2613.

(78) Chen, J. G.; Egner, P. A.; Ng, D.; Jacobson, L. P.; Munoz, A.; Zhu, Y. R.; Qian, G. S.; Wu, F.; Yuan, J. M.; Groopman, J. D.; Kensler, T. W. Reduced Aflatoxin Exposure Presages Decline in Liver Cancer Mortality in an Endemic Region of China. Cancer Prev. Res. (Phila) 2013, 6, 1038-1045.

(79) Egner, P. A.; Chen, J. G.; Wang, J. B.; Wu, Y.; Sun, Y.; Lu, J. H.; Zhu, J.; Zhang, Y. H.; Chen, Y. S.; Friesen, M. D.; Jacobson, L. P.; Munoz, A.; Ng, D.; Qian, G. S.; Zhu, Y. R.; Chen, T. Y.; Botting, N. P.; Zhang, Q.; Fahey, J. W.; Talalay, P.; Groopman, J. D.; Kensler, T. W. Bioavailability of Sulforaphane From Two Broccoli Sprout Beverages: Results of a Short-Term, Cross-Over Clinical Trial in Qidong, China. Cancer Prev. Res. (Phila) 2011, 4, 384-395.

(80) Kensler, T. W.; Ng, D.; Carmella, S. G.; Chen, M.; Jacobson, L. P.; Munoz, A.; Egner, P. A.; Chen, J. G.; Qian, G. S.; Chen, T. Y.; Fahey, J. W.; Talalay, P.; Groopman, J. D.; Yuan, J. M.; Hecht, S. S. Modulation of the Metabolism of Airborne Pollutants by Glucoraphanin-Rich and Sulforaphane-Rich Broccoli Sprout Beverages in Qidong, China. Carcinogenesis 2012, 33, 101-107. 
(81) Egner, P. A.; Chen, J. G.; Zarth, A. T.; Ng, D. K.; Wang, J. B.; Kensler, K. H.; Jacobson, L. P.; Munoz, A.; Johnson, J. L.; Groopman, J. D.; Fahey, J. W.; Talalay, P.; Zhu, J.; Chen, T. Y.; Qian, G. S.; Carmella, S. G.; Hecht, S. S.; Kensler, T. W. Rapid and Sustainable Detoxication of Airborne Pollutants by Broccoli Sprout Beverage: Results of a Randomized Clinical Trial in China. Cancer Prev. Res. (Phila) 2014, 7, 813-823.

(82) Fahey, J. W.; Talalay, P.; Kensler, T. W. Notes From the Field: "Green" Chemoprevention As Frugal Medicine. Cancer Prev. Res. (Phila) 2012, 5, 179188.

(83) Fox, R. J.; Miller, D. H.; Phillips, J. T.; Hutchinson, M.; Havrdova, E.; Kita, M.; Yang, M.; Raghupathi, K.; Novas, M.; Sweetser, M. T.; Viglietta, V.; Dawson, K. T. Placebo-Controlled Phase 3 Study of Oral BG-12 or Glatiramer in Multiple Sclerosis. N. Engl. J. Med. 2012, 367, 1087-1097.

(84) Pergola, P. E.; Raskin, P.; Toto, R. D.; Meyer, C. J.; Huff, J. W.; Grossman, E. B.; Krauth, M.; Ruiz, S.; Audhya, P.; Christ-Schmidt, H.; Wittes, J.; Warnock, D. G. Bardoxolone Methyl and Kidney Function in CKD With Type 2 Diabetes. N. Engl. J. Med. 2011, 365, 327-336.

(85) Conaway, C. C.; Wang, C. X.; Pittman, B.; Yang, Y. M.; Schwartz, J. E.; Tian, D.; McIntee, E. J.; Hecht, S. S.; Chung, F. L. Phenethyl Isothiocyanate and Sulforaphane and Their N-Acetylcysteine Conjugates Inhibit Malignant Progression of Lung Adenomas Induced by Tobacco Carcinogens in A/J Mice. Cancer Res. 2005, 65, 8548-8557. 
(86) Chung, F. L.; Conaway, C. C.; Rao, C. V.; Reddy, B. S. Chemoprevention of Colonic Aberrant Crypt Foci in Fischer Rats by Sulforaphane and Phenethyl Isothiocyanate. Carcinogenesis 2000, 21, 2287-2291.

(87) Munday, R.; Mhawech-Fauceglia, P.; Munday, C. M.; Paonessa, J. D.; Tang, L.; Munday, J. S.; Lister, C.; Wilson, P.; Fahey, J. W.; Davis, W.; Zhang, Y. Inhibition of Urinary Bladder Carcinogenesis by Broccoli Sprouts. Cancer Res. 2008, 68, 1593-1600.

(88) Singh, S. V.; Warin, R.; Xiao, D.; Powolny, A. A.; Stan, S. D.; Arlotti, J. A.; Zeng, Y.; Hahm, E. R.; Marynowski, S. W.; Bommareddy, A.; Desai, D.; Amin, S.; Parise, R. A.; Beumer, J. H.; Chambers, W. H. Sulforaphane Inhibits Prostate Carcinogenesis and Pulmonary Metastasis in TRAMP Mice in Association With Increased Cytotoxicity of Natural Killer Cells. Cancer Res. 2009, 69, 2117-2125.

(89) Kensler, T. W.; Egner, P. A.; Agyeman, A. S.; Visvanathan, K.; Groopman, J. D.; Chen, J. G.; Chen, T. Y.; Fahey, J. W.; Talalay, P. Keap1-Nrf2 Signaling: a Target for Cancer Prevention by Sulforaphane. Top. Curr. Chem. 2013, 329, 163-177.

\section{FIGURE LEGENDS}

Figure 1. Scheme of Keap1-Nrf2 interactions. Under homeostatic conditions, Nrf2 is bound by Keap1 through the "hinge" (ETGE) and "latch" (DLG) domains of Nrf2. Upon association, Nrf2 is ubiquitinated ( $\mathrm{Ub}$ ) by the Cul3 ubiquitin ligaase complex, marking it for proteasomal degradation. Induction of Nrf2 signaling by sulforaphane through thiocarbamylation at Cys151 (cysteine 151) may lead to disruption or perturbation of the 
Cul3 association with Keap1 and abrogation of Nrf2 ubiquitination. Newly synthesized Nrf2 thereby escapes proteasomal degradation and translocates to the nucleus where it accumulates and activates the transcription of its target genes. Target genes of Nrf2 include multiple isoforms of glutathione S-transferases (GSTs) which in turn can conjugate acrolein or metabolites of benzene, and polycyclic aromatic hydrocarbons leading to the excretion of these air pollutants in urine as mercapturic acids.

Figure 2. Glucoraphanin in broccoli is converted to sulforaphane either by plant myrosinases, or if the plant myrosinases have been denatured by cooking, by bacterial $\beta$ thioglucosidases in the human colon. Sulforaphane is passively absorbed and rapidly conjugated with glutathione by glutathione S-transferases (GSTs), then metabolized sequentially by $\gamma$-glutamyl-transpeptidase (GTP), cysteinyl-glycinease (GCase) and Nacetyltransferase (NAT). The conjugates are actively transported into the systemic circulation where the merapturic acid and its precursors are urinary excretion products. Deconjugation may also occur to yield the parent isothiocyanate, sulforaphane. The mercapturic acid and cysteine conjugate forms are the major urinary metabolites of sulforaphane ${ }^{79}$. 
TABLE 1. Chemopreventive Activity of Sulforaphane in Animal Models

\begin{tabular}{|c|c|c|c|c|c|}
\hline Organ Site & $\begin{array}{l}\text { Species } \\
\text { Strain }\end{array}$ & Carcinogen & $\begin{array}{l}\text { SFN Formulation } \\
\text { Or Dose }\end{array}$ & $\begin{array}{l}\text { Endpoints } \\
\text { Measured }\end{array}$ & Reference \\
\hline $\begin{array}{l}\text { Mammary } \\
\text { gland }\end{array}$ & $\begin{array}{l}\text { Rat }+ \\
\text { SD }\end{array}$ & DMBA & $\begin{array}{l}75 \text { or } 150 \mu \mathrm{mol} \text { SFN p.o.; } \\
\text { q.d. X } 5\end{array}$ & $\begin{array}{l}\text { Reduced tumor } \\
\text { incidence \& } \\
\text { multiplicity }\end{array}$ & 62 \\
\hline $\begin{array}{l}\text { Mammary } \\
\text { gland }\end{array}$ & $\begin{array}{l}\text { Rat }+ \\
\text { SD }\end{array}$ & DMBA & $\begin{array}{l}1 \mathrm{~mL} \text { broccoli sprout } \\
\text { extract containing } 25,100 \\
\mu \text { mol glucosinolates or } 25 \text {, } \\
50,100 \mu \text { mol } \\
\text { isothiocyanates; daily } \\
\text { gavage on days } 47-51\end{array}$ & $\begin{array}{l}\text { Reduced tumor } \\
\text { incidence }\end{array}$ & 57 \\
\hline Skin & $\begin{array}{l}\text { Mouse }+ \\
\text { C57B16 }\end{array}$ & DMBA & $\begin{array}{l}100 \text { nmol SFN, topical, } \\
\text { q.d. X } 14 \text { before DMBA }\end{array}$ & $\begin{array}{l}\text { Reduced tumor } \\
\text { incidence in } \\
\text { Nrf } 2 \text { wild-type } \\
\text { but not Nrf2 } \\
\text { null mice }\end{array}$ & 67 \\
\hline Skin & $\begin{array}{l}\text { Mouse } q \\
\text { CD-1 }\end{array}$ & $\begin{array}{l}\mathrm{DMBA} \rightarrow \\
\mathrm{TPA}\end{array}$ & $\begin{array}{l}1,5 \text { or } 10 \mu \mathrm{mol} \text { SFN } \\
\text { topical before TPA }\end{array}$ & $\begin{array}{l}\text { Reduced tumor } \\
\text { incidence \& } \\
\text { multiplicity }\end{array}$ & 66 \\
\hline Skin & $\begin{array}{l}\text { Mouse }{ }^{+} \\
\text {SKH-1 }\end{array}$ & UV & $\begin{array}{l}100 \mu \mathrm{L} \text { broccoli sprout } \\
\text { extract containing } 1 \mu \mathrm{mol} \\
\text { SFN topical }\end{array}$ & $\begin{array}{l}\text { Reduced tumor } \\
\text { incidence \& } \\
\text { multiplicity }\end{array}$ & 64 \\
\hline Skin & $\begin{array}{l}\text { Mouse } q \\
\text { SKH-1 }\end{array}$ & UV & $2.5 \mu \mathrm{mol}$ SFN topical & $\begin{array}{l}\text { Reduced tumor } \\
\text { incidence \& } \\
\text { multiplicity }\end{array}$ & 65 \\
\hline Stomach & $\begin{array}{l}\text { Mouse } q \\
\text { ICR }\end{array}$ & $\mathrm{B}[\mathrm{a}] \mathrm{P}$ & $\begin{array}{l}7.5 \mu \text { mol SFN q.d. X } 9 \\
\text { before/after B[a]P }\end{array}$ & $\begin{array}{l}\text { Reduced tumor } \\
\text { incidence } \\
\text { inNrf2 wild- } \\
\text { type but not } \\
\text { Nrf2 null mice }\end{array}$ & 68 \\
\hline Lung & $\begin{array}{l}\text { Mouse } q \\
\text { A/J }\end{array}$ & $\begin{array}{l}\mathrm{B}[\mathrm{a}] \mathrm{P}+ \\
\mathrm{NNK}\end{array}$ & $\begin{array}{l}3 \mathrm{mmol} / \mathrm{kg} ; 20 \text { wks after } \\
\text { carcinogen administration, } \\
\text { fed diet containing SFN } \\
\text { wks } 21-42 .\end{array}$ & $\begin{array}{l}\text { Reduced tumor } \\
\text { incidence }\end{array}$ & 85 \\
\hline Colon & $\begin{array}{l}\text { Rat } \sigma^{\pi} \\
\text { F344 }\end{array}$ & $\mathrm{AOM}$ & $\begin{array}{l}20 \text { or } 50 \mu \text { mol SFN q.d. } X \\
3 \text { during initiation; } 5 \text { or } 20 \\
\mu \text { mol } 3 X / w k \text { X } 8 \text { wk post- } \\
\text { initiation }\end{array}$ & $\begin{array}{l}\text { Reduced } \\
\text { incidence of } \\
\text { aberrant crypt } \\
\text { foci }\end{array}$ & 86 \\
\hline Bladder & $\begin{array}{l}\text { Rat } q \\
\text { SD }\end{array}$ & N-OH-BBN & $160 \mu \mathrm{mol} / \mathrm{kg} / \mathrm{d}$ & $\begin{array}{l}\text { Reduced tumor } \\
\text { incidence }\end{array}$ & 87 \\
\hline Prostate & Mouse $\sigma^{\lambda}$ & TRAMP & $\begin{array}{l}6 \mu \mathrm{mol} / \mathrm{mouse} ; 3 X \mathrm{wk}, \\
\text { p.o. for } 17-19 \mathrm{wk}\end{array}$ & $\begin{array}{l}\text { Reduced tumor } \\
\text { incidence }\end{array}$ & 88 \\
\hline
\end{tabular}


Abbreviations: SD rats, Sprague-Dawley rats; SFN, sulforaphane; GR, glucoraphanin; DMBA, dimthylbenz[a]anthracene; TPA, 12-O-tetradecanoylphorble ester; UV, ultraviolet light; B[a]P, benzo[a]pyrene; AOM, azoxymethane; N-OH-BBN, N-butyl-N(4-hydroxybutyl) nitrosamine; TRAMP, transgenic adenocarcinoma of mouse prostate; NNK: 4-(methylnitrosamino)-1-(3-pyridyl)-1-butanone.

TABLE 2. Phase I \& II Clinical Cancer Chemoprevention Trials with Sulforaphane (SFR)and/or Glucoraphanin (GRR)-Rich Broccoli Sprout Preparations

\begin{tabular}{|c|c|c|c|c|}
\hline Agent & Dose and Schedule & $\begin{array}{l}\text { Sample } \\
\text { Size } \\
\text { (duration) }\end{array}$ & Biomarker Modulation & References \\
\hline $\begin{array}{l}\text { Broccoli } \\
\text { Sprout } \\
\text { Beverage } \\
\text { GRR }\end{array}$ & $225 \mu \mathrm{mol} \mathrm{GRR}$ & $\begin{array}{l}12 \\
\text { (1 day) }\end{array}$ & $\begin{array}{l}\text { Bioavailability study only: } \sim 5 \% \\
\text { administered GR recovered in urine } \\
\text { as SFN metabolites }\end{array}$ & 89 \\
\hline $\begin{array}{l}\text { Broccoli } \\
\text { Sprout } \\
\text { Beverage } \\
\text { SFR }\end{array}$ & $\begin{array}{l}200 \mu \text { mol SFR } 1 \mathrm{~h} \\
\text { before surgery }\end{array}$ & 8 (1 day) & $\begin{array}{l}\text { Bioavailability study only: } \sim 2 \mu \mathrm{M} \\
\text { concentration of SFN in mammary } \\
\text { epithelium following elective } \\
\text { reduction mammoplasty }\end{array}$ & 63 \\
\hline $\begin{array}{l}\text { Broccoli } \\
\text { Sprout } \\
\text { Beverage } \\
\text { GRR }\end{array}$ & $\begin{array}{l}\text { Placebo, q.d. } \\
\text { or } \\
400 \mu \mathrm{mol} \text { GRR q.d. }\end{array}$ & $\begin{array}{l}200 \\
(14 \text { days })\end{array}$ & $\begin{array}{l}9 \% \text { decrease in urinary excretion of } \\
\text { AFB-N7-gua DNA adducts at } 10 \\
\text { days; } 10 \% \text { decrease in pollutant } \\
\text { PheT excretion }\end{array}$ & 77 \\
\hline $\begin{array}{l}\text { Broccoli } \\
\text { Sprout } \\
\text { Beverage } \\
\text { GRR } \leftrightarrow \text { SFR } \\
\text { Cross-over }\end{array}$ & $\begin{array}{l}\text { Run-in } \rightarrow \text { GRR }(800 \\
\mu \text { mol }) \rightarrow \text { wash-out } \\
\rightarrow \text { SFR }(150 \mu \text { mol }) \\
\text { Run-in } \rightarrow \text { SFR } \rightarrow \\
\text { wash-out } \rightarrow \text { GRR }\end{array}$ & $\begin{array}{l}50 \\
(24 \text { days })\end{array}$ & $\begin{array}{l}\text { Glucoraphanin and sulforaphane } \\
\text { elimination pharmacokinetics; } 20 \text { - } \\
50 \% \text { increases in urinary excretion } \\
\text { of mercapturic acid conjugates of } \\
\text { air pollutants: acrolein, ethylene } \\
\text { oxide, crotonaldehyde, benzene }\end{array}$ & 80 \\
\hline $\begin{array}{l}\text { Broccoli } \\
\text { Sprout } \\
\text { Beverage } \\
\text { GRR + SFR } \\
\text { Blend }\end{array}$ & $\begin{array}{l}\text { Placebo } \\
\text { GRR }(600 \mu \mathrm{mol})+ \\
\text { SFR }(40 \mu \mathrm{mol})\end{array}$ & $\begin{array}{l}291 \\
(12 \text { weeks) }\end{array}$ & $\begin{array}{l}\text { Rapid and sustained increases in the } \\
\text { rate of urinary elimination of } \\
\text { mercapturic acids of benzene }(61 \%) \\
\text { and acrolein }(23 \%) \text {, but not } \\
\text { crotonaldehyde }\end{array}$ & 81 \\
\hline
\end{tabular}




\begin{tabular}{|c|c|c|c|c|}
\hline $\begin{array}{l}\text { Broccoli } \\
\text { Sprout } \\
\text { Extract } \\
\text { GRR }\end{array}$ & $\begin{array}{l}\text { GRR }(200 \mu \text { mol } \\
\text { GR/d) orally in four } \\
50 \mu \text { mol capsules } \\
\text { taken once daily }\end{array}$ & $\begin{array}{l}20 \\
\text { (20 weeks) }\end{array}$ & $\begin{array}{l}1 \text { in } 20 \text { patients achieved a } 50 \% \\
\text { decline in PSA levels while } \\
\text { receiving sulforaphane treatment. }\end{array}$ & $\begin{array}{l}\text { ClinicalTrials.g } \\
\text { ov } \\
\text { NCT01228084 } \\
\text { Sulforaphane in } \\
\text { Treating } \\
\text { Patients With } \\
\text { Recurrent } \\
\text { Prostate Cancer }\end{array}$ \\
\hline $\begin{array}{l}\text { Broccoli } \\
\text { Sprout } \\
\text { Extract in } \\
\text { Mango Juice }\end{array}$ & $\begin{array}{l}\text { Placebo } \\
\text { SFR }\end{array}$ & 14 days & $\begin{array}{l}\text { To determine a decrease in the } \\
\text { mean proliferative rate measured by } \\
\text { Ki67\%; increase in transcript \& } \\
\text { protein levels of enzymes known to } \\
\text { be modulated by SFN as well as } \\
\text { qualitative assessment of } \\
\text { morphological changes in DCIS } \\
\text { specimens and adjacent normal } \\
\text { tissue }\end{array}$ & $\begin{array}{l}\text { ClinicalTrials.g } \\
\text { ov } \\
\text { NCT00982319 } \\
\text { Effect of } \\
\text { Sulforaphane } \\
\text { in Broccoli } \\
\text { Sprout } \\
\text { Extract on } \\
\text { Breast Tissue }\end{array}$ \\
\hline $\begin{array}{l}\text { Broccoli } \\
\text { Sprout } \\
\text { Extract (BSE) }\end{array}$ & $\begin{array}{l}\text { BSE daily for } 3 \\
\text { weeks }\end{array}$ & 3 weeks & $\begin{array}{l}\text { Evaluate the effect of broccoli } \\
\text { sprout extract on levels of DNA } \\
\text { adducts in participants who smoke }\end{array}$ & $\begin{array}{l}\text { ClinicalTrials.g } \\
\text { ov } \\
\text { NCT00255775 } \\
\text { Broccoli Sprout } \\
\text { Extract in } \\
\text { Preventing } \\
\text { Lung Cancer in } \\
\text { Smokers }\end{array}$ \\
\hline $\begin{array}{l}\text { Broccoli } \\
\text { Sprout } \\
\text { Extract }\end{array}$ & $\begin{array}{l}\text { Placebo; broccoli } \\
\text { sprout extract } \\
3 \mathrm{X} \text { daily for 2-8 } \\
\text { weeks }\end{array}$ & 8 weeks & $\begin{array}{l}\text { Change in Ki- } 67 \text { and apoptosis as } \\
\text { assessed at baseline and after } \\
\text { completion of study therapy; } \\
\text { change in } \mathrm{H} 3 \text { and } \mathrm{H} 4 \text { as assessed by } \\
\text { IHC at baseline and after } \\
\text { completion of study therapy; } \\
\text { change in HDAC activity as } \\
\text { assessed at baseline and after } \\
\text { completion of study therapy }\end{array}$ & $\begin{array}{l}\text { ClinicalTrials.g } \\
\text { ov } \\
\text { NCT00843167 } \\
\text { Broccoli Sprout } \\
\text { Extract in } \\
\text { Treating } \\
\text { Women who } \\
\text { have had a } \\
\text { Mammogram } \\
\text { and Breast } \\
\text { Biopsy }\end{array}$ \\
\hline $\begin{array}{l}\text { Broccoli } \\
\text { Sprout Extract } \\
\text { (BSE) and } \\
\text { Garlic Oil }\end{array}$ & $\begin{array}{l}\text { BSE placebo } \\
\text { garlic oil placebo } \\
\text { garlic oil + BSE } \\
\text { placebo } \\
\text { BSE + garlic oil } \\
\text { placebo BSE \& }\end{array}$ & 21 days & $\begin{array}{l}\text { Change in HDAC activity; change } \\
\text { in histone acetylation }\end{array}$ & $\begin{array}{l}\text { ClinicalTrials.g } \\
\text { ov } \\
\text { NCT01543074 } \\
\text { Dietary Histone } \\
\text { Deacetylase } \\
\text { Inhibitors }\end{array}$ \\
\hline
\end{tabular}




\begin{tabular}{|c|c|c|c|c|}
\hline & $\begin{array}{l}\text { Garlic Oil } \\
\text { Capsule per day for } \\
7 \text { days }\end{array}$ & & & \\
\hline $\begin{array}{l}\text { Broccoli Seed } \\
\text { Extract } \\
\text { GRR }\end{array}$ & $\begin{array}{l}\text { Placebo } \\
250 \mathrm{mg} \text { of } \\
\text { broccoli seed extract } \\
\text { ( } 30 \mathrm{mg} \text { sulforaphane } \\
\text { glucosinolate), } 8 \\
\text { capsules ( } 4 \text { capsules } \\
\text { B.I.D.) daily }\end{array}$ & 4-8 weeks & $\begin{array}{l}\text { Investigate the effects of broccoli } \\
\text { sprout supplementation on DNA } \\
\text { methylation status and proliferation } \\
\text { markers in a pre-biopsy setting }\end{array}$ & $\begin{array}{l}\text { ClinicalTrials.g } \\
\text { ov } \\
\text { NCT01265953 } \\
\text { Chemopreventi } \\
\text { on of Prostate } \\
\text { Cancer, HDAC } \\
\text { Inhibition and } \\
\text { DNA } \\
\text { Methylation } \\
\text { Status }\end{array}$ \\
\hline $\begin{array}{l}\text { Broccoli } \\
\text { Sprout Extract } \\
\text { SFR }\end{array}$ & $\begin{array}{l}50,100 \text { or } 200 \mu \mathrm{mol} \\
\text { SFN capsules, taken } \\
\text { orally, once a day } \\
\text { for } 28 \text { days }\end{array}$ & 2 years & $\begin{array}{l}\text { Visual changes of atypical nevi: } \\
\text { size, border, color; cellular changes } \\
\text { of the atypical nevi; } \\
\text { effects of sulforaphane on STAT1 } \\
\text { and STAT3 expression. }\end{array}$ & $\begin{array}{l}\text { ClinicalTrials.g } \\
\text { ov } \\
\text { NCT01568996 } \\
\text { A Pilot Study } \\
\text { Evaluation of } \\
\text { Sulforaphane in } \\
\text { Atypical Nevi-- } \\
\text { Precursor } \\
\text { Lesions: }\end{array}$ \\
\hline
\end{tabular}

Abbreviations: SFN, sulforaphane; SFR, sulforaphane-rich; GR, glucoraphanin; GRR, glucoraphanin-rich; AFB-N7-gua, aflatoxin B1-N7-guanine; PheT, phenanthrene tetraol; PSA, prostate specific antigen; HDAC, histone deacetylase. 
FIGURE 1

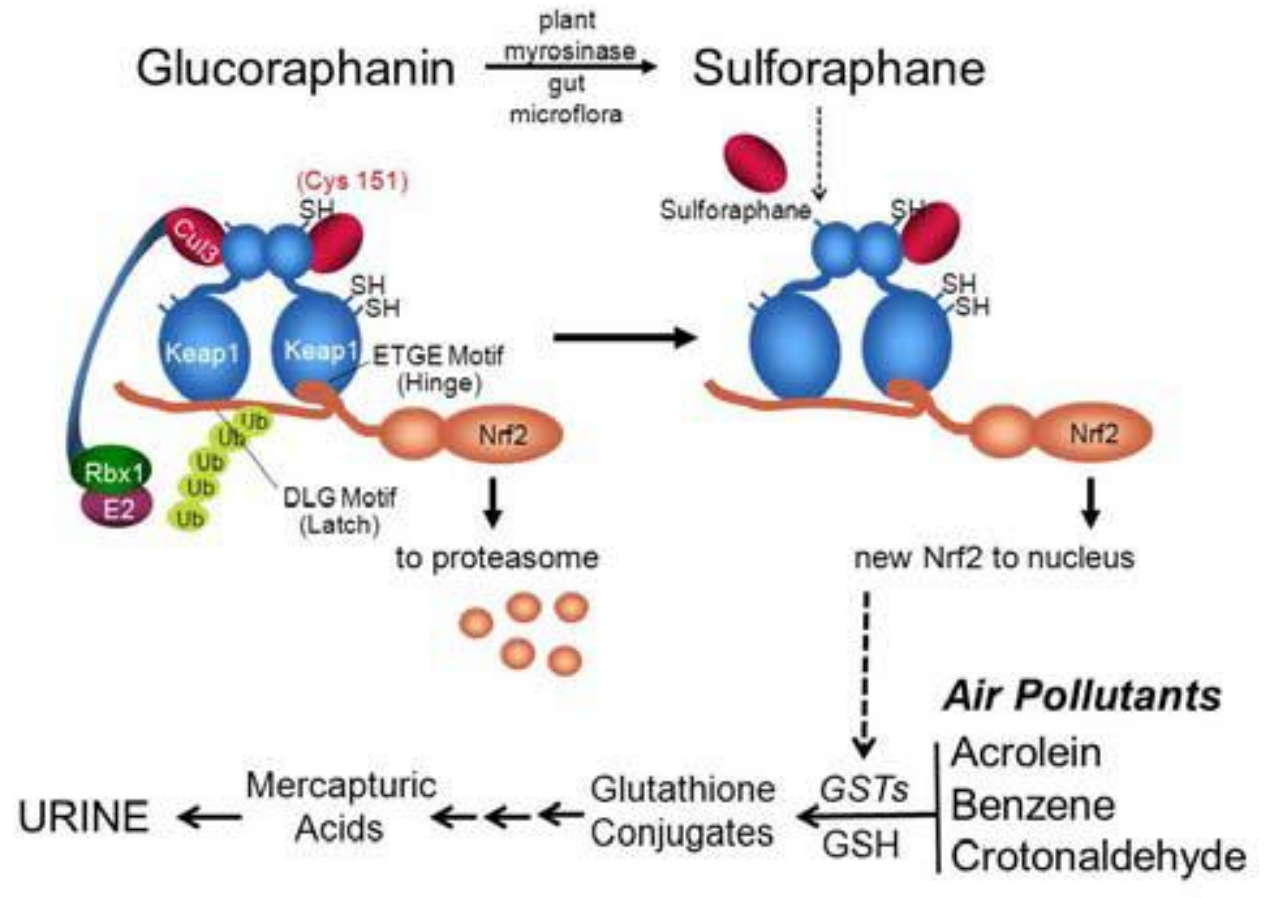




\section{FIGURE 2}
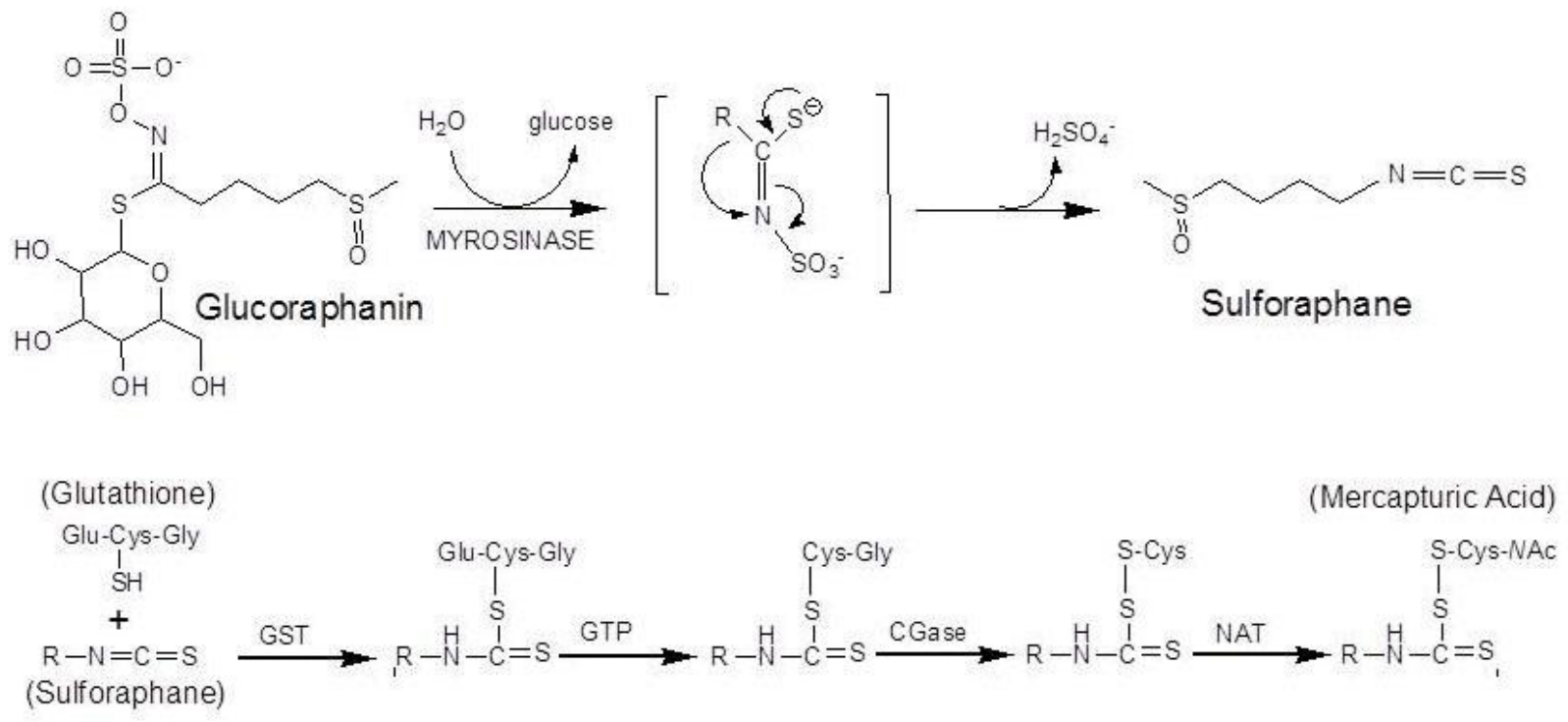